IJMS 22 (1), 47-56 (2015)

\title{
ACCESS TO TECHNICAL ASSISTANCE: A CASE STUDY OF SUPPLIERS IN THE MALAYSIAN AUTOMOTIVE INDUSTRY
}

\author{
KADZRINA ABDUL KADIR \\ HASSAN ALI \\ School of Business Management \\ Universiti Utara Malaysia \\ ON KIT TAM \\ College of Business \\ RMIT University, Melbourne, Australia
}

\begin{abstract}
Technology transfer has been an important area in supplier development as suppliers are expected to develop their capabilities with their technical partners. The literature has focused on supplier development programmes implemented by automakers for their suppliers. However, less focus has been on the suppliers who received them, particularly the dependent suppliers: suppliers whose major buyers account for $20 \%$ or more of their sales. Thus, the aim of this paper is to examine the experiences of the dependent suppliers with their technical partners, which was part of the supplier development program that was implemented by their major buyers. This study was based on interviews with seven supplier organisations in the Malaysian automotive industry. Findings suggest that both positive and less positive experiences were received by the dependent suppliers, and possible explanations were discussed.
\end{abstract}

Keywords: Supplier development, technical assistance, technology transfer, automotive industry, qualitative study, multiple-case study.

\section{Introduction}

For developing and emerging countries like Malaysia to improve its competitiveness, there is a need to focus on research and innovation which can be achieved through collaboration (Bhatt, 2011). Developing countries have less access to globally capable suppliers, particularly in high-intensive industries such as the automotive industry. Therefore, 
there is a need for domestic automakers as well as foreign automakers in countries such as Malaysia to build up the local suppliers' expertise as well as research on how they are doing this (Abdul Kadir, Tam, \& Hassan, 2011). One such programme is the supplier development programme implemented by both local and foreign automakers. One activity in the programme is partnering the local suppliers with foreign technical assistance (TA) partners in the hope of establishing technology transfer between the two organisations. Literature suggests however, that technology transfer is not certain or as hoped for. For example, Ivarsson and Avlstam (2004) noted that lower levels of technology transfer could occur during supplier development programmes. Therefore, the aim of this paper is to examine the experiences of dependent suppliers (suppliers with major buyers who account for $20 \%$ or more of their sales (Carr, Kaynak, \& Hartley, 2008) with their Technical Assistance (TA) partners as they participated in their buyers' supplier development programme. This paper will look into 'how' the experiences from the dependent suppliers' point of view were and 'why'?

\section{Literature Review}

Supplier development programmes are activities that buyers could implement in order to develop the capability of their suppliers. Talluri and Narasimhan (2004) consider supplier development programmes among the processes in a strategic sourcing chain. Selecting the suppliers to be involved in these programmes is also important. Supplier selection is another important process when buyers focus on strategic sourcing. The literature on supplier selection emphasizes on selecting the right supplier through focusing on criteria (Dickson, 1966), segmenting suppliers based on buyers' needs (Kraljic, 1983) or the four types of relationship based on supplier segments (Svensson, 2004). Kraljic (1983) stated that a supplier could be segmented into strategic, bottleneck, leverage or non-critical item supplier. Svensson (2004) extended that research into the four supplier segment relationships between a buyer and a seller: family, business partner, friendly or transactional. If a supplier is a dependent supplier, the supplier could then be categorized into either transactional or friendly (Svensson, 2004).

For technology transfer to occur between organisations, learning and knowledge acquisition must exist in the environment (Nobeoka, Dyer, \& Madhokl, 2002). The authors suggest that technology transfer 
could occur when a supplier has access to multiple customers thus necessitating a broad customer strategy. Kotabe, Martin and Domoto (2003) suggest that a systematic buyer-supplier relationship would facilitate technology transfer. Kotabe et al. (2003) define technology transfer as a technical exchange which takes place over the long-term and within a structured relationship. Thus the technical assistance series which has a long-term duration and within the structure of a supplier development programme would enhance technology transfer to occur.

The literature suggests that there is still a need to understand how technology transfer occurs and how suppliers learn. Ivarsson and Alvstam (2004) noted in their study on technology transfer that local suppliers face difficulties in technology transfer when dealing with global automakers, suggesting there is a need to understand the process. In Malaysia, Othman, Mohammad and Bakar (2005), in their paper on local suppliers in Malaysia, also brought up similar issues while Li, Humphreys, Yeung and Cheng (2007) suggest that more understanding is needed on suppliers' participation in the supplier development programmes. Thus, in summary, the literature suggests that the technology transfer process between two organisations is not automatic and issues could occur that reduce or perhaps cease technology transfer from occurring. The technology transfer process is a part of the whole learning process of suppliers and the literature suggests that more research needs to be done in this area. Therefore, this paper intends to look at the Technical Assistance (TA) programme between local suppliers and their TA partners where technology transfer is the objective and examine the local suppliers' experience.

\section{Methodology}

For this study, qualitative research using the multiple-case study approach was used. Interviews were conducted with senior managers and executives of seven organizations. Eight key respondents were interviewed and were selected based on their knowledge of both operation levels as well as top management decision-making. The interviews focused on dependent suppliers' experience of the supplier development programme, emphasizing on their experience with their technical assistance partners. Data was analysed based on the Miles and Huberman methods (1994). In the three-phase analysis as suggested by the authors, after transcribing interviews, data was coded and arranged into tables and matrices and finally 
conclusions were drawn and verified. The seven cases differed in three dimensions: size, industry-base (plastic and metal) and ownership (Malaysian-owned and former foreign-owned). Reliability is through coding checks and data quality checks. External validity was based on theoretically diverse sampling based on the three dimensions. To maintain anonymity, the seven cases were given initials unrelated to their actual identities.

\section{Findings}

The objectives of this paper were to answer this research question: How were the experiences of the dependent suppliers receiving technical assistance from their Technical Assistance (TA) partners and why? Table 1 below summarises the findings for each of the seven Dependent Suppliers (DS). As could be seen, the first four DS still had some contact with their TA while the last three no longer had any contact with their TA. The last column ('Remark') gives reasons that the DS had mentioned.

Table 1

Access to Technical Assistance

\begin{tabular}{|c|c|c|c|c|c|}
\hline Case & $\begin{array}{l}\text { No. of } \\
\text { TA }\end{array}$ & Country & Years & Area & Remark \\
\hline GN & 1 & Japan & $\begin{array}{l}\text { Since } \\
\text { beginning }\end{array}$ & $\begin{array}{l}\text { Manufacturing } \\
\text { technology }\end{array}$ & $\begin{array}{l}\text { Symbiotic. TA helped } \\
\text { GN's development. } \\
\text { Has JV with TA. }\end{array}$ \\
\hline \multirow[t]{2}{*}{ LI } & \multirow[t]{2}{*}{$\begin{array}{l}4 \text { - longest } \\
2\end{array}$} & Japan & $\begin{array}{l}\text { Since } \\
\text { beginning }\end{array}$ & Transport & \multirow{2}{*}{$\begin{array}{l}\text { Emphasize on } 4 \\
\text { elements in TA } \\
\text { agreements including } \\
\text { training and assistance } \\
\text { during parts } \\
\text { development }\end{array}$} \\
\hline & & US & $\begin{array}{l}\text { Not } \\
\text { mentioned }\end{array}$ & Painting & \\
\hline CS & 1 & Taiwan & $\begin{array}{l}\text { Since } \\
\text { beginning }\end{array}$ & $\begin{array}{l}\text { Parts development, } \\
\text { supplier }\end{array}$ & $\begin{array}{l}\text { CS was part of Taiwan } \\
\text { TA before being } \\
\text { bought over by a new } \\
\text { Malaysian owner }\end{array}$ \\
\hline \multirow[t]{2}{*}{ VA } & 2 & Japan & $\begin{array}{l}\text { Since } \\
\text { beginning }\end{array}$ & $\begin{array}{l}\text { Japanese } \\
\text { suppliers/ } \\
\text { parts development }\end{array}$ & $\begin{array}{l}\text { Consult with TA when } \\
\text { developing new parts }\end{array}$ \\
\hline & & Korea & 4 years & Parts development & \\
\hline
\end{tabular}


IJMS 22 (1), 47-56 (2015)

\begin{tabular}{|c|c|c|c|c|c|}
\hline Case & $\begin{array}{l}\text { No. of } \\
\text { TA }\end{array}$ & Country & Years & Area & Remark \\
\hline$\overline{\mathrm{KA}}$ & NIL & NIL & NIL & NIL & $\begin{array}{l}\text { Has stopped TA. Has } \\
1 \text { freelance consultant. } \\
\text { Felt knowledgeable to } \\
\text { do on their own. But } \\
\text { maybe TA on safety } \\
\text { parts }\end{array}$ \\
\hline SU & NIL & NIL & NIL & NIL & $\begin{array}{l}\text { Has stopped TA. } \\
\text { However has MoU } \\
\text { with machine } \\
\text { manufacturer for } \\
\text { advice }\end{array}$ \\
\hline PR & NIL & NIL & NIL & NIL & $\begin{array}{l}\text { No TA. } 2 \text { unsuccessful } \\
\text { experiences with TA. } \\
\text { 1-Felt taken advantage } \\
\text { of thru cheap labour. } \\
\text { 2-Only co-patent } \\
\text { owner, no technical } \\
\text { assistance }\end{array}$ \\
\hline
\end{tabular}

Source. Research Data.

\section{Maintain vs No Longer Maintain}

Technical Assistance (TA) partners who provide assistance to suppliers were also sometimes referred by the respondents as Technical Collaborators (TC). As shown in Table 1, four suppliers have had beneficial TA experience, and the programmes were still ongoing. Three suppliers had stopped their TA. Of these three, only one supplier linked the reason to terminate TA to a bad experience. The other two suppliers felt that they had gained sufficient knowledge that they no longer needed the TA. They continued, however, to have access to consultants for advice. The access category was divided across the two areas: plastics-based and metal-based suppliers. Therefore, TA access was not differentiated based on area.

\section{TA Country of Origin}

Based on the country of origin of ongoing TA, Asian countries were the majority, with Japan (3 TA), Korea (1) and Taiwan (1). The US was the only non-Asian TA. It is noted that all of the Japanese TAs had had relationships with suppliers from the beginning - that is, when suppliers first started their operations. This would be in the range of between 15-25 years. The other TA, which had also started since the 
beginning with a local supplier, came from Taiwan. However, CS, the supplier, had actually been part of the Taiwan company, thus, longterm relationship is expected.

\section{Areas for Assistance}

For the ongoing TAs, the areas in which suppliers were given assistance were parts development (LI, CS, VA) and training and manufacturing technology (GN). The focus on parts development is significant as the aim of the Malaysian auto industry is to increase the capability of local suppliers to develop local parts for local automakers.

\section{Emphasis of Different Automakers}

In the interviews, suppliers made the point that new parts development was emphasized at LA1 but less emphasized at LA2. LA1 developed their own cars while LA2 cars were based on the Japanese cars of LA2's Japanese owner. GN was the only supplier who had substantial access to TA and the only supplier who had a joint venture with their TA. This relationship differed when compared to other TAsupplier relationships that were based on renewed contracts every 3-5 years.

\section{Positive vs Less Positive Experiences}

\section{No longer have TA's}

In Table 1, the data suggest that some suppliers had more positive experiences compared to others. For example, out of the three DS that had ceased links with their TAs, one of them (PR) explained that their company had less positive experiences which led them to cease having TAs. The first experience was when PR had sent several of their staff for training in Japan. However, the staff found that little training was given and they were tasked with working there. Though they were paid their (Malaysian) salaries by the TA, these were much lower compared with their Japanese counterparts as Japan had a higher labour cost. Another experience as explained by PR was that though they were given some partial credit as co-patent owners for one part, little technology transfer was received from their TA. Thus it was these types of experiences that led them to cease links with their TA and currently (as at the time of interview) they had no TA partners. 
For the other two DS, though they had also ceased having TAs, they still maintained some contact and consulted with their TAs on some occasions. For example, KA still maintained some contact with their TA through their freelance consultant. They explained that they felt they had enough knowledge to go on their own, but if they felt they needed more information, they could access their freelance consultant. For SU, they no longer had any TAs however, they had an agreement with a machine manufacturer to consult for advice.

\section{Still have TAs}

For other DS however, they have had positive experiences and either continued with their TA partners, or increased their TA partners. Most of the DS started by being DS to LA1, and thus mostly had TA partners from Japan. They later established TA links with partners from others countries such as Korea, US or Taiwan, as evident from Table 1.

One successful TA partnership is that with GN. The DS had established their link with their TA partner from the very beginning and not only maintained it but had evolved what the GN respondent stated as a 'symbiotic' relationship. The GN respondent explained that both companies had grown together and were now important partners to the other in the relationship. This is reflected through the joint venture that GN has with their TA partner.

For LI, this company has four TA partners. Two were picked as they were the TA partners that LI had the longest duration of relationship with. One was from Japan, which they had as TA from the beginning while the other was from the US. The LI respondent noted that for a successful TA partnership, it was important to emphasise four areas in the TA agreement, of which two were the training to be received from the TA partners and the assistance from the TA partner during parts development.

Thus, the findings section answers the main research question of this paper: How were the experiences of the dependent suppliers receiving technical assistance from their Technical Assistance (TA) partners and why? 


\section{Discussion}

This research paper has presented the findings of a study with the aim of examining the experiences of dependents suppliers with their Technical Access partners (TA) as they participated in a supplier development programme implemented by their buyers. This paper intended to answer the question of 'how' the experiences were received by the dependent suppliers and 'why'. Overall, the dependent suppliers differ in several ways in their relationship with TA partners. Most had long-term duration and their TA partners were essential in helping them with technology transfer in areas such as parts development, manufacturing technology and others. Most of the TAs were Japanese in the beginning and later TA partners came other countries. Overall, the experience was perceived to be mostly positive. Still, only four suppliers maintained or increased their TA partners while others ceased their TA partnership. Reasons for ending the partnership include feeling that they received enough knowledge for them to go on their own or only accessing them on an ad-hoc basis or lastly, due to having a less positive relationship. The only supplier acknowledging a less positive relationship perceived that they were taken advantage of by their TA partner and thus wanted to end the relationship. However, one other supplier had such a positive relationship with their TA partner that now both are in a joint-venture project together.

This research is in line with Kotabe et al. (2003) which suggested that technology transfer would more likely occur in a structured and systematic buyer-supplier relationship in a long-term duration. The TA partners had relationships of more than 10 years and this seemed to help their access to technology from their partners, for those who still maintained their TA partners. In addition, this research also reflects the suggestions of Nobeoka et al. (2002) which linked larger number of buyers to access more knowledge and information. All of the dependent suppliers had more than one major buyer. This research also reflects the suggestions of Ivarsson and Alvstam (2004) which suggested that technology transfer that occur between different organisations might result in a lower level of technology transfer than expected - which might explain the result for the less positive experiences of the dependent suppliers. The results above suggest that types of knowledge that exist could either be 'sticky' [knowledge that is costly to move from one location to another (Von Hippel, 1994)] or not (see Lipinski, 2012). Thus, 'sticky knowledge' 
could be a factor on knowledge transfer and thus some organisations are better able to leverage on their knowledge base compared to others (Lipinski, 2012).

\section{Conclusion}

This study has indicated that dependent suppliers overall have more positive than less positive experiences though this does not necessarily mean that they will continue their TA relationship. The study suggests that technology transfer process is arduous and needs long-term duration for success and thus both parties need to be ready for the high level of commitment ahead.

\section{References}

Abdul Kadir, K., Tam O. K., \& Ali, H. (2011). Supplier selection of dependent suppliers: Case studies in the Malaysian automotive industry, 25th Annual Australian and New Zealand Academy of Management Conference, Proceedings of the 25th ANZAM Wellington, New Zealand, 7-9 $9^{\text {th }}$ December 2011, paper 052.

Bhatt, P. R. (2011). Competitiveness of Malaysia: A comparative Study. International Journal of Management Studies, 18(2), 23-41.

Carr, A. S., Kaynak, H., \& Hartley, J. L. (2008). Supplier dependence: impact on supplier's participation and performance. International Journal of Operations and Production Management, 28(9), 899-916.

Dickson, G. (1966). An analysis of vendor selection system and decisions. Journal of Purchasing, 2, 28-41.

Ivarsson, I., \& Alvstam, C. G. (2004). International technology transfer to local suppliers by Volvo trucks in India. Tijd voor Econ \& Soc Geog, 95(1), 27-43.

Kotabe, M., Martin, X., \& Domoto, H. (2003). Gaining from vertical partnerships: Knowledge transfer, relationship duration, and supplier performance improvement in the US and Japanese automotive industries. Strategic Management Journal, 24(4), 293-316.

Kraljic, P. (1983). Purchasing must become supply management. Harvard Business Review, 61,109-117.

Li, W, Humphreys, P. K., Yeung, A. C. L., \& Cheng, T. C. E. (2007). The impact of specific supplier development efforts on buyer competitive advantage: An empirical model. International Journal of Production Economics, 106, 230-247. 
IJMS 22 (1), 47-56 (2015)

Lipinski, J. (2012) Knowledge stickiness, knowledge management, and their impact on firm level competitive advantage. International Journal of Management Studies, 19(2), 1-13.

Miles, M. B., \& Huberman, A. M. (1994). Qualitative data analysis: An expanded sourcebook (2nd ed.). United States of America: Sage Publications.

Nobeoka, K., Dyer, J. H., \& Madhok, A. (2002). The influence of customer scope on supplier learning and performance in the Japanese automobile industry. Journal of International Business Studies, 33(4), 717-736.

Othman, S. N., Mohammad, N., \& Bakar, N. A. (2005). Technology transfer for developing suppliers' technological capability. Journal of Technology Management and Entrepreneurship, 3(2), $1-18$.

Svensson, G. (2004). Supplier segmentation in the automotive industry. International Journal of Physical Distribution $\mathcal{E}$ Logistics Management, 34(1), 12-38.

Talluri, S., \& Narasimhan, R. (2004). A methodology for strategic sourcing. European Journal of Operational Research, 154, 236-250.

Von Hippel, E. (1998). Economics of product development by user the impact of sticky local information. Management Science, 44(5), 629-644. 